\title{
UPOTREBA KARIPRAZINA U LEČENJU UNIPOLARNE \\ DEPRESIJE: PRIKAZ \\ SLUČAJA
}

\section{Sara Dodić ${ }^{1}$ \\ Bojana Dunjić Kostić ${ }^{1,2}$ \\ Stefan Jerotić ${ }^{1}$ \\ Nikola Lalović ${ }^{1}$ \\ Maja Ivkovićc ${ }^{1,2}$ \\ Maja Pantović Stefanovićc ${ }^{1,2}$}

1 Klinika za psihijatriju,

Univerzitetski klinički centar Srbije, Beograd, Srbija

2 Medicinski fakultet,

Univerzitet u Beogradu,

Beograd, Srbija

\footnotetext{
doi: 10.5937/engrami43-34089

prispelo: 22. 09. 2021.

prihvaćeno: 25. 09. 2021.

objavljeno onlajn: 25. 09. 2021.
}

\section{Sažetak}

Celoviti tretman afektivnih poremećaja, i to posebno različitih formi depresije još uvek predstavlja značajan izazov u kliničkom radu. Aktuelni prikaz slučaja ima za cilj upravo razmatranje izazova u svakodnevnoj kliničkoj praksi u slučajevima kompleksne dijagnostike, diferencijalne dijagnostike i tretmana rekurentne, teške depresivne epizode, kao i razmatranje uloge dodatne terapije.

U aktuelnom radu prikazana je pacijentkinja srednjih godina, lečena na Klinici za psihijatriju Univerzitetskog kliničkog centra Srbije, u okviru rekurentne, teške depresivne epizode, sa prethodnim višestrukim pokušajima suicida. Na prethodno primenjeni anti- 
depresiv iz grupe inhibitora ponovnog preuzimanja serotonina i noradrenalina i stabilizator raspoloženja litijum karbonat, pacijentkinji je u terapiju uveden atipični antipsihotik kariprazin što je dovelo do značajnog kliničkog poboljšanja i subjektivnog zadovoljstva pacijentkinje.

Upotreba atipičnih antipsihotika, među njima i kariprazina, kao psihofarmaka sa multidimenzionalnim delovanjem u lečenju teških i izazovnih oblika afektivnih poremećaja, od posebne je važnosti sa aspekta svakodnevne kliničke prakse. Samo detaljno, integrativno i individualno prilagođeno sagledavanje terapijskih mogućnosti, bazirano na naučnim saznanjima i praktičnim iskustvima, može dovesti do njihove adekvatne, pravovremene i utemeljene kliničke primene, čiji je cilj pre svega bolje funkcionisanje pacijenata sa afektivnim poremećajima kako po objektivnim kriterijumima, tako i prema subjektivnom/ ličnom doživljaju funkcionisanja.

Ključne reči: afektivni poremećaji, depresija, augmentacija, atipični antipsihotici, kariprazin

\section{IZJAVA O KONFLIKTU INTERESA}

Ne postoji konflikt interesa.

\section{UVOD}

Celoviti tretman afektivnih poremećaja, i to kako različitih formi depresije, tako i bipolarnog afektivnog poremećaja još uvek predstavlja značajan izazov u kliničkom radu. Sa jedne strane problemi duševnog funkcionisanja u okviru ovih poremećaja heterogeni su po svojim bio-psiho-socijalnim dimenzijama, a sa druge strane, na praktičnom nivou, nivou njihovog tretmana, često zahtevaju upravo usklađivanje prethodno navedenih dimenzija. U okviru ovoga, pored osnovne vodilje u medicini "primum non nocere", psihijatar kliničar ima pred sobom kompleksan zadatak - da balansira sam izbor medikamentozne terapije (koji zavisi od nekoliko činilica kao što su istorija prethodnog odgovora na terapiju, komorbidna psihijatrijska i somatska oboljenja, lepeza neželjenih efekata, same farmakološke osobine leka, dostupnost leka na tržištu itd.), i pruži odgovarajuću odgovarajuću podršku i obezbedi primenu psihoterapijskog modaliteta kako bi tretman bio celovit i doveo do stabilizacije i oporavka kako objektivno tako i u dimenziji ličnog/subjektivnog doživljaja ${ }^{[1]}$.

Rekurentni depresivni poremećaj (RDP), posebno ukoliko se karakteriše teškim depresivnim epizodama je $u$ značajnoj meri onesposobljavajući mentalni poremećaj koji odlikuje niz heterogenih simptoma kao što su depresivno raspoloženje, smanjenje interesovanja 
za aktivnosti koje su ranije donosile zadovoljstvo, doživljaj pada energije, izmene u kognitivnom funkcionisanju, vegetativni simptomi, prome na nivou voljno nagonskih dinamizama u smislu promena na nivou ciklusa budnost-spavanje, izmene u sferi apetita, seksualne želje, ali i prisustvo suicidnih ideja/tendencija $^{[2]}$. RDP je učestalo psihijatrijsko oboljenje sa visokim morbiditetom i mortalitetom. Prema podacima Svetske zdravstvene organizacije (SZO), procenjuje se da $10-15 \%$ opšte populacije iskusi klinički značajnu depresiju tokom života, kao i da oko 5\% muškaraca i 9\% žena iskusi neki depresivni poremećaj tokom godine ${ }^{[3]}$. Dalje, RDP je povezan i sa nizom somatskih tegoba i bolesti, te je zapaženo da je povezan sa povećanim rizikom za razvoj bolesti kao što su dijabetes melitus, kardiovaskularne cerebrovaskularne bolesti (insult) ${ }^{[4]}$, što dodatno povećava zdravstveni, socijalni i ekonomski teret ove bolesti.

Uprkos širokom spektru terapijskih mogućnosti i antidepresivima sa različitim mehanizmima delovanja, nepotpun ili odsutan odgovor na antidepresivnu terapiju i dalje predstavlja veliki problem prilikom lečenja pacijenata sa $\mathrm{RDP}^{[5]}$. Približno polovina pacijenata sa RDP ne odgovori na inicijalnu antidepresivnu terapiju ${ }^{[6]}$. U STAR ${ }^{\star} D$ studiji je pokazano da čak skoro dve trećine pacijenata ne dostigne punu remisiju nakon adekvatne primene selektivnih inhibitora ponovnog preuzimanja serotonina
(SSRI), kao prvog terapijskog koraka, a da trećina bolesnika ostaje sa nekim od simptoma i nakon četiri adekvatna, sukcesivna koraka promene farmakoterapijskog protokola. Dodatno, prema studiji koja je navedena pokazano je da se sa svakim narednim korakom smanjuje verovatnoća odgovora na terapiju, a povećava verovatnoća relapsa ${ }^{[7,8]}$.

Aktuelni protokoli za lečenje teraporezistentne depresije podrazumevaju primenu alternativnog antidepresiva iz iste ili druge klase (SSRI, selektivni inhibitori ponovnog preuzimanja serotonina i noradrenalina - SNRI), kombinovanje dva antidepresiva iz različitih klasa i adjuvantnu terapiju koja podrazumeva augmentaciju efikasnosti antidepresiva sa nekim od lekova iz druge grupe, npr. stabilizatorom raspoloženja ili atipičnim antipsihotikom ${ }^{[1,9-11]}$. Augmentacija drugim klasama lekova može obezbediti prednost za postizanje optimalnih terapijskih efekata ${ }^{[12]}$. Atipični antipsihotici se koriste u kombinaciji sa antidepresivima da bi poboljšali terapijski odgovor, a ovakva njihova primena je pokazana kroz kliničku efikasnost u randomizovanim kontrolisanim studijama ${ }^{[9,10]}$. Trenutno jedini antipsihotici odobreni od strane Američke agencije za hranu i lekove (U.S Food \& Drug Administration - FDA) kao adjuvantna terapija za lečenje $\mathrm{RDP}$ su atipični antipsihotici aripiprazol, brekspiprazol, kvetiapin sa produženim oslobađanjem i olanzapin (u kombinaciji sa fluoksetinom) ${ }^{[11,13,14]}$, 
iako se i drugi atipični antipsihotici, prema svom farmakološkom profilu mogu razmatrati za lečenje RDP.

Kariprazin je dopamin-serotonin parcijalni agonista, u istoj farmakološkoj podklasi kao i brekspiprazol $i$ aripiprazol [15]. Deluje kao parcijalni agonista D2 i D3 receptora, sa značajno većim afinitetom za D3 receptore. Takođe deluje kao parcijalni agonista na 5-HT1A receptore, pokazuje antagonizam u odnosuna 5-HT2A receptore i 5-HT2B receptore i minimalni antagonizam na 5-HT2C, 5-HT7 i H1 receptore ${ }^{[16]}$. Njegov farmakološki profil višestruko ukazuje na to da bi kariprazin, kao i neki drugi atipični antipsihotici ${ }^{[11,13]}$, mogao biti koristan u regulaciji ne samo psihotičnih već i afektivnih simptoma ${ }^{[17-19]}$.

Naime, D3 dopaminski receptori su identifikovani kao jedna od potencijalnih meta za lečenje depresije ${ }^{[15]}$. Ovi receptori su pretežno eksprimirani u regionima mozga koji su povezani sa motivacijom i ponašanjem, a vezani su za sistem nagrade ${ }^{[20]}$, što je navelo istraživače da razmišljaju u pravcu da kariprazin može imati i pozitivne efekte kako na kogniciju tako i na samo raspolože$n j \mathrm{e}^{[11,17-19]}$, što navedeni lek (koji deluje kao parcijalni agonista D3 receptora) čini obećavajućim kandidatom za terapiju RDP. Pored navedenog, kariprazin deluje i kao parcijalni agonista 5-HT1A receptora, što može pojačati efekte antidepresiva iz klase SSRI ili postići delovanje koje preko istih receptora ispoljavaju trazodon ili noviji antidepresivi kao što su vilazodon i vortioksetin ${ }^{[11,13,14,21]}$. Dalje, delovanje kariprazina i na druge receptore kao što je 5HT7 bi moglo dodatno da objasni njegov uspeh u tretmanu poremećaja raspoloženja ${ }^{[22,23]}$.

Cilj aktuelnog prikaza slučaja je razmatranje izazova u svakodnevnom kliničkom radu u slučajevima kompleksne dijagnostike, diferencijalne dijagnostike i tretmana velikog depresivnog poremećaja, kao i razmatranju uloge dodatne terapije kariprazinom.

\section{PRIKAZ SLUČAJA}

Pacijentkinja R.L., starosti $49 \pm 2$ godine (inicijali i starost pacijentknje izmenjeni) javila se na Kliniku za psihijatriju, Univerzitetskog kliničkog centra Srbije zbog perzistiranja tegoba iz depresivnog spektra u vidu sniženog raspoloženja, gubitka interesovanja, energije, pada koncentracije, problema pažnje, nemogućnosti doživljavanja zadovoljstva, pada opšteg funkcionisanja koji se manifestovao kako na profesionalnom tako i na porodičnom i emotivnom planu, kao i postojanja suicidalnih ideja. Nakon eksploracije u ambulantnim uslovima (detaljno uzete anamneze i dobijanja heteroanamnestičkih podataka od strane porodice pacijentkinje i iz prethodnih medicinskih izveštaja), dobijeni su podaci koji su ukazivali da je pacijentkinja prethodno, $u$ više navrata, lečena u različitim psihijatrijskim 
institucijama kako ambulantno, tako i hospitalno, kao i da je tretirana heterogenim farmakoterapijskim protokolima. Navedeno, prema anamnestičkim i heteroanamnestičkim podacima, nije dovelo do postizanja potpune redukcije simptomatologije i povratka na premorbidni nivou funkcionisanja u smislu perzistentnog „zaostajanja“ tegoba koje su se manifestovale doživljajem gubitka energije i nemogućnosti postizanja zadovoljstva u aktivnostima koje su ranije dovodile do ovog doživljaja (anhedonije), izraženog odsustva motivacije kao i nemogućnosti koncentracije, lošije pažnje, uz stalno prisutnu ambivalentnost oko suicidalnosti. Do javljanja u našu instituciju pacijentkinja je u tri navrata pokušala suicid (medikamentozni). $\mathrm{U}$ dogovoru sa pacijentkinjom i porodicom pacijentkinja je hospitalizovana radi detaljne dijagnostike, diferencijalne dijagnostike i pronalaženja optimalnog farmakoterapijskog protokola.

Naime, prve tegobe pacijentkinje su se javile postepeno prema njenom doživljaju, u njenoj 39/40 godini života, bez jasnog provokativnog faktora, a $u$ vidu neraspoloženja, prenaglašene potrebe za spavanjem, kompletne pasivizacije i apragmatizma (nije ustajala iz kreveta, nije imala volje da se bavi svakodnevnim kućnim i profesionalnim obavezama, niti da uživa u bliskim odnosima sa porodicom), redukovala je sve socijalne kontakte jer su je razgovori "umarali", niti je imala dovoljnu kon- centraciju da učestvuje u istima. Tada je, kako je navela, i imala značajan gubitak apetita (praćen značajnim gubitkom kilograma). Bila je stalno zabrinuta, teško je uspevala da se fokusira na bilo kakav zadatak, te zbog svega navedenog i ličnog doživljaja iscrpljenosti i neefikasnosti u različitim sferama funkcionisanja, u jednom trenutku i napušta posao. Sve navedene tegobe su u značajnoj meri odstupale od njenog prethodnog funkcionisanja (prema anamanestičkim i heteroanamnestičkim podacima), bila je osoba koja je uvek bila radno efikasna, kako profesionalno (radila je na zahtevnoj i odgovornoj poziciji i uživala poštovanje), tako i u porodičnom miljeu. Vremenom, pored navedenog, sve učestalije su joj se javljale misli o bezvrednosti života/gubitku smisla, te je nakon izvesnog vremena pacijentkinja pokušala da sebi oduzme život ispijanjem veće količine medikamenata, nakon čega je i započela psihijatrijsko lečenje. Od značaja iz lične i porodične anamneze evidentirano je da pacijentkinja nema istoriju prethodnog somatskog ili neurološkog oboljenja. Nikada nije imala povrede glave, krize svesti ili bilo kakve operacije i nalazi se u menopauzi. Evidentiran je pozitivan psihijatrijski hereditet (starija sestra se leči psihijatrijski usled depresivne simptomatologije).

Lečenja koja su usledila (ambulantna i hospitalna) su uvek bila realizovana zbog prethodno navedene simptomatologije (koja je fluktuirala u intenzitetu) 
kao i nakon pokušaja suicida. Kako je već navedeno i pored primene različitih farmakoterapijskih protokola i delimičnog ili nepotpunog odgovora na tretman i perzistiranja tegoba u ravni voljnonagonskog i kognitivnog, postojala je realna potreba za celovitom reevaluacijom dijagnoze i diferencijalno dijagnostičkih alternativa, uz potrebu da terapijskom optimizacijom.

$\mathrm{U}$ psihičkom statusu na prijemu u našu instituciju pacijentkinja je bila slabije održavane spoljašnjosti i lične higijene, sedela je "skrušeno", pognute glave, povremeno kršeći prste kao izraz anksioznosti. Mimika i gestikulacija su odavale tužan izraz lica, povremeno se zaplače sećajući se kako je nekada funkcionisala. Govor je bio tih, slabije modulisan, odgovori na pitanja su bili kratki, šturi, sa produženom latencom. Pacijentkinja je bila svesna, ispravno orijentisana, bez perceptivnih distorzija. Pažnju je usmeravala na sadržaje vezane za svoje aktuelno stanje i na negativnu aticipaciju budućnosti. Misaoni tok je bio usporen, u sadržaju mišljenja su bile prisutne depresivne elaboracije. Pamćenje i upamćivanje bili su kompromitovani. Raspoloženje je bilo depresivno polarisano, afekat slabije modulisan, uz postojanje anksioznosti. Voljno-nagonski dinamizmi su bili kompromitovani u vidu hipobulije, anhedonije, apragmatizma, hipoapeticije, hipersomnije, tendencije ka socijalnoj restrikciji, pada globalnog funkcionisanja. U trenutku prijema postojale su suicidalne misli na nivou ideacije.

U cilju celovite dijagnostike i diferencijalne dijagnostike na prijemu u našu ustanovu pacijentkinji su izmereni vitalni i antopometrijski parametri i obavljene kompletne laboratorijske analize (Tabela 1). Pacijentkinji je urađena magnetna rezonanca endokranijuma, kako bi se isključile organske promene. Nalaz je bio u morfološkim granicama. Ključni nalazi psihološkog testiranja ukazivali su da su intelektualni kapaciteti na nivou proseka, uz smetnje u funkcionisanju u domenu pažnje i kratkoročnog pamćenja. Nisu bili registrovani markeri psihotičnosti i patologije ličnosti već samo depresivnog poremećaja. Radi objektivne procene težine psihopatologije, pacijentkinji su urađeni i psihometrijski testovi pre uvođenja karipazina, nakon 4 nedelje i nakon 8 nedelja od započinjanja tretmana (Tabela 3 ).

Pacijentkinja je od terapije, u momentu prijema, uzimala duloksetin 90mg/dan, litijum 900mg/dan, klozapin $50 \mathrm{mg} /$ dan i diazepam $15 \mathrm{mg} /$ dan. Usled icrpljivanja farmakoterapijskih mogućnosti (i iz uvida u prethodne farmakoterapijske protokole; Tabela 4 - pojedini psihofarmaci nisu bili u maksimalnim dozama, ali su bili u dozama maksimalne podnošljivosti za pacijentkinju usled pojave neželjenih efekata) pacijentkinji je u farmakoterapijski protokol uveden lek kariprazin u dozi od $1.5 \mathrm{mg} / \mathrm{dan}$, a isključen klozapin. Pacijentkinja je re- 
dovno praćena tokom 8 nedelja. $\mathrm{U}$ tom periodu primećeno je značajno poboljšanje u skorovima na psihometrijskim testovima. Nije došlo do značajnijih promena vitalnih i antropometrijskih parametara, kao ni do promena u laboratorijskim parametrima (Tabela 1 , Tabela 2). Tokom tretmana, evidentirano je značajno poboljšanje u svim dimenzijama psihičkog funkcionisanja a u smislu stabilizacije na timohormičkom i bihejvioralnom planu, kao i na nivou kognitivnog funkcionisanja, a što su potvrdile i finalne psihometrijske procene (Tabela 3), te je pacijentkinja otpuštena sa savetom nastavka terapije koja je dovela do uspostavljanja stabilne remisije i redovnim kontrolama psihijatra.

\section{DISKUSIJA}

Aktuelni rad prikazuje slučaj lečenja pacijentkinje sa teškom depresivnom epizodom RDP kod koje je primena atipičnog antipsihotika kariprazina uspešno dovela do značajnog poboljšanja mentalnog funkcionisanja i opšte funkiconalnosti.

Neuspeh da se postigne i održi remisija, kao i prisustvo rezidualnih simptoma nakon akutne terapije RDP predstavljaju neke od najsnažnijih prediktora relapsa i lošeg funkcionalnog i psihosocijalnog ishoda kod pacijenata koji boluju od $\mathrm{RDP}^{[24]}$, a što je aktuelnim prikazom slučaja pokušano da se prikaže kroz detaljnu reevaluacije pret- hodnih farmakoterapijskih protokola, ali i notiranje perzistirajućih rezidualnih simptoma. S obzirom da efikasnost tretmana velikog depresivnog poremećaja opada sa svakim sukcesivnim korakom izmene farmakoterapijskog protokola ${ }^{[8]}$, a da je održavanje remisije povezano sa poboljšanjem dugoročnih ishoda bolesti i smanjenim rizikom od neželjenih ishoda kao što je rezistencija na terapiju ${ }^{[24]}$, javlja se potreba za razmatranjem novih farmakoloških mogućnosti koje će ovim pacijentima omogućiti adekvatan ili makar bolji terapijski ishod.

Postavlja se pitanje zašto neki depresivni pacijenti odgovore na terapiju samo jednim antidepresivom, dok je drugima neophodno nekoliko različitih terapijskih pokušaja da bi postigli remisiju, ako je uopšte ikada u potpunosti i postignu $^{[25]}$. RDP je kompleksna bolest koja se ispoljava širokim spektrom različitih simptoma i znakova, od kojih je svaki verovatno determinisan jedinstvenim neuronskim krugom ${ }^{[26]}$. Usled vrlo varijabilnog načina ispoljavanja bolesti, dva pacijenta mogu da ispune kriterijume za RDP, a da pri tom dele samo neke od znakova i simptoma bolesti ${ }^{[24]}$. Takođe RDP varira u težini i toku bolesti, kao i u komorbiditetima koji je prate, što sve zajedno dodatno otežava precizno razumevanje etiologije kod ove heterogene grupe pacijenata $^{[25]}$. Smatra se da je serotonin uključen u regulaciju raspoloženja, regulaciju ciklusa budnost-spavanje, regulaciju apetita, seksualno funkcioni- 
sanje, percepciju bola, učenje i memoriju. Noradrenalin ima ulogu u procesima uključenim u regulaciju spavanja, motivaciju i opreznost. Dopamin je uključen u kognitivne procese, motorne funkcije, energiju i razvoj zavisnosti ${ }^{[27,28]}$. Smatra se da su simptomi, pre nego dijagnostička kategorija, povezani sa specifičnim izmenama neurotransmisije, i na osnovu toga predložena je primena kriterijuma istraživačkog domena (Research Domain Criteria - RDoC) da bi se napravio sistem za klasifikaciju baziran na biološki determinisanim varijablama ${ }^{[26]}$, što bi olakšalo razumevanje i terapijski pristup poremećajima koji uključuju takve simptome. Istovremeno, savremena razmatranja u psihofarmakologiji predlažu preimenovanje najvažnijih grupa psihotropnih lekova u smislu izbegavanja fokusa na njihovo kliničko delovanje tj. indikaciono područije (npr. antipsihotici, antidepresivi itd.), a korišćenja farmakološkog dejstva (serotonin-dopamin antagonisti, inhibitori ponovnog preuzimanja serotonina itd.).

$S$ obzirom da, prema $\operatorname{STAR}^{\star} \mathrm{D}$ studiji, značajan deo pacijenata ne reaguje na prvu liniju antidepresivne terapije, nije neobično što raste upotreba antipsihotika kao adjuvantne terapije kako bi se povećala efikasnost antidepresiva prilikom lečenja RDP. Smatra se da augmentacija antidepresiva atipičnim antipsihoticima poboljšava profil farmakološkog delovanja i profil neželjenih efekata. Međutim, principi kojima atipični antipsihotici doprinose antidepresivnim efektima i dalje nisu u potpunosti razjašnjeni ${ }^{[29]}$.

Iako je depresija tradicionalno povezivana sa disfunkcijom serotonergičkog i noradrenergičkog sistema, sve veći broj istraživanja prepoznaje ulogu dopaminergičkog sistema u patogenezi $\mathrm{RDP}^{[26]}$. Preciznije, zbog svoje lokalizacije, D3 dopaminski receptori se sve češće povezuju sa psihijatrijskim bolestima. Ovi receptori pokazuju specifičnu distribuciju u mozgu, sa predominantnom ekspresijom u limbičkim strukturama mozga koje su uključene u regulaciju motivacije, ponašanja vezanog za sistem nagrade i kognitivne funkcije. Takođe, D3 dopaminski receptori su i autoreceptori lokalizovani u presinaptičkim regionima, koji imaju inhibitoran efekat na dopaminsku neurotransmisiju, kao i na sintezu i oslobađanje dopamina. S obzirom na kompleksnost dopaminergičkog sistema neurotransmisije, a još nedovoljno poznate mehanizme nastanka pojedinih simptoma kod RDP, parcijalni agonizam dopaminskih receptora predstavlja obećavajuću terapijsku strategiju, u skladu sa konceptom „dopaminske stabilizacije“, jer jedna supstanca može i da poveća i da smanji dopaminsku aktivnost u skladu sa potrebama samog neuronskog kruga ${ }^{[30]}$. Upravo delovanje kariprazina na ovu klasu receptora, može ići u prilog kliničkog poboljšanja u sferi afektiviteta i kognitivnih perfomansi u konkretnom slučaju naše pacijentkinje, praćene između ostalog subjektivnim 
doživljajem postojanja veće motivisanosti, postojanja energije i vraćanja interesovanja, te i bolje koncentracije i pažnje i poboljšanjem raspoloženja.

Kariprazin je antipsihotik druge generacije koji ima parcijalnu agonističku aktivnost na D2 i D3 receptore ${ }^{[31]}$. Možda je najupečatljivije svojstvo kariprazina njegov veliki afinitet za D3 receptore, koji ne samo da je veći nego za D2 receptore, nego je veći od afiniteta samog dopamina za ove receptore, što ga čini jedinstvenom farmakološkom opcijom koja za razliku od ostalih agonista/antagonista vrši blokadu ovih recetora koja nije reverzibilna dejstvom dopami$\mathrm{na}^{[13]}$. Antagonizam na D3 dopaminske receptore može objasniti zašto ovaj antipsihotik deluje prokognitivno i antidepresivno, a pomaže i kod negativnih simptoma shizofrenije ${ }^{[31]}$. U regionima mozga bogatim dopaminom, D3 receptorski parcijalni agonizam ima ukupan efekat smanjenja dopaminergične neurotransmisije i na taj način smanjenje psihotičnih simptoma i simptoma manije. Sa druge strane postoje indicije da agonizam D3 receptora u korteksu povećava opreznost i budnost ${ }^{[32]}$. Izmene u mezolimbičkom dopaminergičkom putu, tačnije njegova hipoaktivnost, možda su odgovorne za anhedoniju, jedan od glavnih simptoma depresije ${ }^{[33]}$, a što je na liniji i aktuelnog prikaza slučaja u kojem je sama anhedonija bila ne samo sastavni deo ponovljenih kliničkih slika, već je bila i “zaostali” simptom koji i pored prethodne primene raznorodnih farmakoterapijskih protokola je perzistirao kroz vreme. Takođe, dopaminergička hipoaktivnost u kortikalnom regionu povezivana je sa negativnim simptomima shizofrenije i kognitivnim deficitom kod obolelih od psihijatrijskih bolesti ${ }^{[23]}$. Eksperimentalna studija, koja je koristila animalni model hronične ekspozicije stresu, pokazala je da kariprazin ima antidepresivne i anksiolitičke efekte. Takođe je pokazano da kariprazin smanjuje anhedonističko ponašanje, jedno od ključnih karakteristika negativnih simptoma shizofrenije i depresije ${ }^{[29]}$.

Pored dopaminskih receptora, kariprazin pokazuje i efekte na serotonergičkim receptorima. Parcijalni agonizam na 5-HT1A receptore može da poveća dopaminsko oslobađanje u mezokortikalnom dopaminergičkom putu, slično parcijalnom agonizmu D3 receptora. $\mathrm{Na}$ taj način bilo koji od ova dva mehanizma može biti odgovoran za antidepresivne efekte kariprazina ${ }^{[32]}$. Parcijalni agonizam na ove receptore, se takođe smatra jednim od načina na koji se poboljšavaju negativni simptomi i kognitivni defi$\mathrm{cit}^{[34]}$. Antagonizam na 5-HT2A receptore omogućava veće dejstvo dopamina u nigrostrijatnom sistemu, na taj način smanjujući ekstrapiramidalne simptome. Blokada 5-HT2C i 5-HT7 receptora verovatno povećava frontokortikalne nivoe noradrenalina i dopamina i na taj način poboljšava kogniciju i cirkadijalni ritam $^{[32]}$. Opisani mehanizmi delovanja 
kariprazina, u smislu efekata na psihičko funkcionisanje naše pacijentkinje, našli su i praktično utemeljenje u aktuelnom slučaju, a što je u skladu sa objektivnim (utemeljenim na psihometrijskim testovima tokom tretmana) i subjektivnim faktorima, koja je kako smo već naveli imala doživljaj poboljšanja kognitivnih perfomansi i balansiranja na timohormičkom i bihejvioralnom planu.

Suprotno od punih antagonista dopaminskih receptora, parcijalni agonizam sugeriše niži rizik od akatizije, tardivne diskinezije, ekstrapiramidalnog sindroma i izmena u sekreciji prolaktina. Nedostatak značajnijeg antagonizma na H1 histaminskim receptorima smanjuje rizik od sedacije i povećanje telesne mase ${ }^{[16]}$. Navedeni farmakološki aspekti su od izrazite važnosti za poznavanje u svakodnevnom kliničkom radu, kako sa aspekta pravovremenog tretmana tako $\mathrm{i}$ nezaobilaznom segmetu razmišljanja o neželjenim efektima, podnošljivosti leka i održavanju komplijanse.

Kariprazin je odobren od strane Američke agencije za hranu i lekove (United States Food and Drug Administration - FDA) za akutno lečenje shizofrenije (1.5-6 mg/dan), akutnu maniju/ maniju sa mešovitim simptomima u sklopu bipolarnog I poremećaja (3$6 \mathrm{mg} / \mathrm{dan}$ ), terapiju održavanja shizofrenije i monoterapiju depresivne epizode u sklopu bipolar I poremećaja ${ }^{[15]}$. Iako još uvek nije odobren kao adjuvantna terapija za lečenje unipolarnog depresivnog poremećaja, već se u kliničkoj praksi koristi u okviru neregistrovane primene leka [14], aktuelno su u toku studije koje ispituju njegovu primenu u ovoj indikaciji $^{[15]}$. U radu Cooper et al. 2020 koji su meta-analitičkim pristupom obrađivali radomizovane kontrolne studije efikasnosti i bezbednosti kariprazina u akutnom tretmanu psihijatrijskih poremećaja pokazano je značajno poboljšanje kontrole intenziteta simptoma kod psihijatrijskih bolesnika uključujući ne samo shizofreniju i bipolarni poremećaj već i depresiju ${ }^{[35]}$. U multicentričnim, randomizovanim, dvostruko-slepim, placebo-kontrolisanim studijama sa paralelnim grupama u kojim je ispitivana njegova efikasnost kao adjuvantne terapije RDP pokazan je statistički značajno bolji terapijski odgovor pacijenata koji su dobijali kariprazin u dozi $2-4.5 \mathrm{mg} /$ dan u odnosu na placebo ${ }^{[13]}$, ali ova razlika nije bila značajna za manje doze $(0.1-0.3 \mathrm{mg} / \mathrm{dan} \text { i } 1.0-2.0 \mathrm{mg} / \mathrm{dan})^{[11,13]}$. Ipak, pacijenti koji su tretirani kariprazinom u dozi 1.0-2.0mg/dan su imali veće srednje smanjenje depresivnih simptoma u poređenju sa placebo $^{[11]}$, što ukazuje na potrebu za daljim istraživanjima na temu mogućnosti primene različitih doznih režima u odnosu na preovlađujuće simptome u okviru RDP.

Aktuelno se vode brojne debate vezane za način dijagnostičkog sagledavanja afektivnih poremećaja i to da li se radi o spektru /kontinuumu poremećaja ili diskontinuiranim poremećajima ${ }^{[36]}$. Možda 
jedna od najvećih promena napravljenih tokom revizije prethodne DSM klasifikacije $^{[37]}$ jeste prepoznavanje mogućnosti pojave mešovitih karakteristika kod velikog depresivnog i sličnih poremećaja. Ovo bi možda predstavljalo vezu između velikog depresivnog poremećaja i bipolarnog poremećaja i jasnije definisalo opravdanost i potrebu za primenom određenih atipičnih antipsihotika u okviru oblika koji su potencijalno prelazni u sistemu unipolarno vs. bipolarno. Upravo, s obzirom na nekonzistentnosti u toku bolesti i odgovoru na antidepresivnu terapiju između različitih grupa pacijenata sa $\mathrm{RDP}^{[38,39]}$, mišljenja smo da je precizna, sveobuhvatna i ciljana analiza psihopatoloških fenomena, toka bolesti i terapijskog odgovora (preciznog, utemeljenog na detaljnoj eksploraciji protokola, doznih režima, vremena provedenog na terapiji, sagledavanja neželjenih efekata, komplijansi itd.) opravdana u svakom pojedinačnom slučaju, a posebno kada se radi o smanjenom ili izostalom odgovoru na antidepresive. Slično ovom razmatranju, u dosadašnjim istraživanjima, pokazano je da pacijenti koji spadaju u grupu koja ispunjava kriterijume za postojanje specifičnih karakteristika (vrsta i težina simptoma) poremećaja lošije odgovaraju na antidepresivnu terapiju nego oni koji nemaju ove karakteristike ${ }^{[40]}$. Iako je trenutni stav da RDP, bez obzira na simptome koji ga prate, treba lečiti antidepresivima u prvoj liniji, teži se ka tome da možda to nije jedino ili najbolje rešenje, već da bi možda antipsihotici širokog delovanja koje uključuje i antidepresivni učinak bili bolja opcija u ovom slučaju ${ }^{[41]}$. Ovo ukazuje na potrebu za rekonceptualizacijom nomenklature lekova na osnovu njihovog farmakološkog dejstva (npr. SDA, SSRI, SNIR itd.), a ne terapijskih indikacija (npr. antipsihotici, antidepresivi itd.), a takođe i dijagnoze i terapije poremećaja raspoloženja, kao i uvođenje lekova u protokole koji bi svojim farmakološkim profilom prevazišao neke od dijagnostičkih nedoumica ${ }^{[15]}$.

\section{ZAKLJUČAK}

Primena atipičnog antipsihotika kariprazina u lečenju RDP može imati svoje značajno mesto. Aktuelni prikaz slučaja ukazuje na važnost sagledavanja svih farmakoloških karakteristika psihofarmaka i razmatranja njihove primene u kliničkoj praksi na osnovu dosadašnjih saznanja o njihovoj farmakodinamici. Posmatranje kariprazina kao ne samo atipičnog antipsihotika već pre svega psihofarmaka sa multidimenzionalnim delovanjem je od izrazite važnosti sa aspekta svakodnevne kliničke prakse. Samo detaljno, integrativno i individualno prilagodjeno sagledavanje terapijskih mogućnosti, bazirano na naučnim saznanjima i praktičnim iskustvima, može dovesti do adekvatne, pravovremene i utemeljene kliničke primene, a čiji je cilj pre svega bolje funkcionisa- 
nje pacijenata kako po objektivnim kri- ličnom doživljaju funkcionisanja pacijeterijumima, tako i prema subjektivnom/ nata sa RDP.

Tabela 1.

Vitalni i antropometrijski parametri na početku i tokom lečenja pacijentkinje.

\begin{tabular}{l|c|c|c} 
Parametri & Dan 1 & Dan 28 & Dan 56 \\
\hline Krvni pritisak (mm/Hg) & $120 / 80$ & $120 / 75$ & $120 / 80$ \\
Puls (br/min) & 74 & 75 & 72 \\
Telesna temperatura ('c) & 36.3 & 36.4 & 36.3 \\
\hline Telesna visina (cm) & 171 & 171 & 171 \\
Telesna težina (kg) & 71.3 & 71.2 & 71.3 \\
Obim struka (cm) & 81.0 & 82.0 & 80.0 \\
BMI (kg/m2) & 25.0 & 24.3 & 24.4 \\
\hline \hline
\end{tabular}

Tabela 2. Laboratorijske analize uradjena na početku i tokom lečenja pacijentkinje

\begin{tabular}{l|c|c|c}
\multicolumn{1}{c|}{ Krvna slika } & Dan 1 & Dan 28 & Dan 56 \\
\hline WBC [3.4-9.7] (10^g/L) & 6.8 & 6.5 & 8.4 \\
RBC [3.86-5.08] (10^g/L) & 4.19 & 4.37 & 4.44 \\
HGB [122-157] (g/L) & 134 & 135 & 139 \\
HCT [0.356-0.470] (L/L) & 0.401 & 0.422 & 0.424 \\
MCV [83.0-97.0] (fL) & 95.8 & 96.5 & 95.4 \\
MCH [27.4-33.9] (pg) & 31.9 & 30.90 & 31.2 \\
MCHC [320.0-360.0] (g/L) & 333.0 & 320.0 & 327.0 \\
PLT [150-450] (10^9/L) (fL) & 218 & 248 & 292 \\
MPV [6.80-10.40] fL & 10.50 & 10.20 & 9.40 \\
PCT [0.107-0.441] \% & 0.228 & 0.250 & 0.274 \\
\hline Biohemijske analize & & & \\
\hline Glukoza [3.9-6.1] (mmol/L) & 4.9 & 5.2 & 4.3 \\
Proteini (ukupni) [62-81]* (g/L) & 70 & 69 & - \\
Albumin [34-55] (g/L) & 43 & 44 & 46 \\
Holesterol (ukupan) [0.0-5.2] (mmol/L) & 5.7 & 5.85 & 7.2 \\
Holesterol, HDL [1.0-9999.0] (mmol/L) & 1.2 & 1.48 & 1.55 \\
Holesterol, LDL* (mmol/L) & - & - & 5.02 \\
Trigliceridi [0.0-1.7] (mmol/L) & 1.54 & 2.21 & 1.39 \\
LDH [220-460] (U/L) & 306 & 314 & 355 \\
CK [0-150] (U/L) & 88 & 27 & 27 \\
\hline
\end{tabular}

${ }^{*}$ Napomena: Holesterol LDL i ukupni protein nisu urađeni na svim praćenjima iz tehničkih razloga 
Tabela 3. Psihometrijske procene na početku i tokom lečenja pacijentkinje

\begin{tabular}{l|c|c|c}
\multicolumn{1}{r|}{ Krvna slika } & Dan 1 & Dan 28 & Dan 56 \\
\hline HAMD-17 & 34 & 13 & 7 \\
MADRS & 31 & 9 & 5 \\
YMRS & 5 & 1 & 1 \\
CGI-S & 5 & 4 & 1 \\
\hline \hline
\end{tabular}

Skraćenice: HAMD-17 - Hamilton Depression Rating Scale (Hamiltono skala za procenu depresivnosti); MADRS - Montgomery-Asberg Depression Rating Scale (Montgomeri- Ašberg skala za procenu depresivnosti); YMRS - Young Mania Rating Scale (Jangova skala za procenu manije), CGI-S - The Clinical Global Impressions Scale - Severity scale (Skala opšteg kliničkog utiska - procena težine bolesti)

Tabela 4. Vrsta i doza psihofarmaka primenjenih tokom ranijih lečenja pacijentkinje

\begin{tabular}{|c|c|}
\hline Primenjeni lekovi & Maksimalna primenjena doza* (mg/dan) \\
\hline \multicolumn{2}{|l|}{ Antidepresivi } \\
\hline Escitalopram & 40 \\
\hline Sertralin & 50 \\
\hline Fluoksetin & 40 \\
\hline Paroksetin & 20 \\
\hline Duloksetin & 90 \\
\hline Mianserin & 30 \\
\hline Mirtazapin & 30 \\
\hline Klomipramin & 200 \\
\hline \multicolumn{2}{|l|}{ Stabilizatori raspoloženja } \\
\hline Lamotrigin & 200 \\
\hline Valproat + valproična kiselina & 1500 \\
\hline Litijum & 900 \\
\hline \multicolumn{2}{|l|}{ Antipsihotici } \\
\hline Olanzapin & 15 \\
\hline Kvetiapin & 500 \\
\hline Aripiprazol & 10 \\
\hline Sulpirid & 150 \\
\hline
\end{tabular}

Napomena: Iz uvida u prethodne farmakoterapijske protokole, prema anamnestičkim, heteroanamnestičkim podacima i podacima iz medicinske dokumentacije, pojedini psihofarmaci nisu bili u maksimalnim dozama, ali su bili u dozama maksimalne podnošljivosti za pacijentkinju (u njihovim višim dozama dolazilo je do pojave neželjenih efekata), a primenjeni su u dovoljno dugom period. 


\section{CARIPRAZINE IN \\ THE TREATMENT OF \\ UNIPOLAR DEPRESSION: \\ CASE REPORT}

\section{Sara Dodic ${ }^{1}$ \\ Bojana Dunjic Kostic ${ }^{1,2}$ \\ Stefan Jerotic ${ }^{1}$ \\ Nikola Lalovic ${ }^{1}$ \\ Maja Ivkovic ${ }^{1,2}$ \\ Maja Pantovic Stefanovic ${ }^{1,2}$}

1 Clinic for Psychiatry,

The University Clinical Centre

of Serbia,

Belgrade, Serbia

2 School of Medicine,

University of Belgrade,

Belgrade, Serbia

doi: $10.5937 /$ engrami43-34089

submitted: 2021/09/22

accepted: 2021/09/25

online published: 2021/09/25

\section{Abstract}

The integrative treatment of affective disorders, especially various forms of depressive disorder, still represents a significant challenge in clinical work. The current case report aims to present the challenges in everyday clinical practice in the case of complex diagnosis, differential diagnosis, and treatment of recurrent, severe depressive episode, as well as to consider the role of adjunctive therapy in its treatment.

The case report presents a middle-aged, female patient, treated at the Clinic of Psychiatry, University Clinical Center of Serbia, for a severe recurrent depressive episode, with previous multiple suicide attempts. She had been initially treated with an antidepressant 
pertaining to the group of serotonin and norepinephrine reuptake inhibitors as well as mood stabilizer lithium carbonate. Due to lack of adequate response, the atypical antipsychotic cariprazine was introduced as adjunctive therapy to her treatment, which led to significant clinical improvement and patient satisfaction.

The use of atypical antipsychotics, including cariprazine, as primarily psychopharmaceuticals with multidimensional action is thus of specific importance from the aspect of everyday clinical practice. Only a detailed, integrative and individually tailored view of therapeutic possibilities, based on scientific knowledge, and practical experience, can lead to their adequate, timely and well-founded clinical application. Furthermore, their primary goal should be better functioning of patients with affective disorders based on the objective criteria and subjective/personal experience of functioning.

Key words: affective disorders, depression, augmentation, atypical antipsychotics, cariprazine

\section{LITERATURA / LITERATURE}

1. Lečić-Toševski D. Nacionalni vodič dobre prakse za lečenje depresije.Ministarstvo zdravlja Republike Srbije. 2012. Dostupno na adresi: https://www.zdravlje.gov.rs/ view_file.php?file_id=675\&cache=sr. Datum pristupa 16.9.2021

2. Otte C, Gold SM, Penninx BW, Pariante CM, Etkin A, Fava M, et al. Major depressive disorder. Nat Rev Dis Prim 2016 21. 2016 Sep 15;2(1):1-20.

3. Lohoff FW. Overview of the Genetics of Major Depressive Disorder. Curr Psychiatry Reports 2010 126. 2010 Sep 17;12(6):539-46.

4. Whooley MA, Wong JM. Depression and cardiovascular disorders. Annu Rev Clin Psychol. 2013 Mar;9:327-54.

5. Fava M. Diagnosis and definition of treatment-resistant depression. Biol Psychiatry. 2003 Apr 15;53(8):649-59.

6. Nemeroff CB. Prevalence and Management of Treatment-Resistant Depression. J Clin Psychiatry. 2007 Jul 16;68(suppl 8):0-0.

7. Warden D, Rush AJ, Trivedi MH, Fava $M$, Wisniewski SR. The STAR*D Project results: a comprehensive review of findings. Curr Psychiatry Rep. 2007 Dec;9(6):449-59.

8. Rush AJ, Triverdi MH, Wisniewski SR, Nierenberg AA, Stewart JW, Warden D, et al. Acute and longer-term outcomes in depressed outpatients requiring one or several treatment steps: a STAR*D report. Am J Psychiatry. 2006;163(11):1905-17.

9. Nelson JC, Papakostas GI. Atypical antipsychotic augmentation in major depressive disorder: a meta-analysis of placebo-controlled randomized trials. Am J Psychiatry. 2009 Sep;166(9):980-91.

10. Wright BM, Eilend EH, Lorenz 
R. Augmentation with atypical

antipsychotics for depression: a review of evidence-based support from the medical literature. Pharmacotherapy. 2013 Mar;33(3):344-59.

11. Fava M, Durgam S, Earley W, Lu K, Hayes R, Laszlovszky I, et al. Efficacy of adjunctive low-dose cariprazine in major depressive disorder: a randomized, double-blind, placebo-controlled trial. Int Clin Psychopharmacol. 2018 Nov 1;33(6):312.

12. Han C, Wang SM, Kato M, Lee SJ, Patkar AA, Masand PS, et al. Second-generation antipsychotics in the treatment of major depressive disorder: current evidence. Expert Rev Neurother. 2013;13(7):851-70.

13. Durgam S, Earley W, Guo H, Li D, Németh G, Laszlovszky I, et al. Efficacy and Safety of Adjunctive Cariprazine in Inadequate Responders to Antidepressants: A Randomized, Double-Blind, PlaceboControlled Study in Adult Patients With Major Depressive Disorder. J Clin Psychiatry. 2016 Mar 23;77(3):0-0.

14. Stahl SM. Stahl's essential psychopharmacology : prescriber's guide (7th ed.). Cambridge, UK ; New York: Cambridge University Press; 2020.

15. Stahl SM, Laredo S, Morrissette DA. Cariprazine as a treatment across the bipolar I spectrum from depression to mania: mechanism of action and review of clinical data. 2020 Feb 12;10:204512532090575.

16. Scarff JR. Cariprazine for Schizophrenia and Bipolar Disorder. Innov Clin Neurosci. 2016 Oct 1;13(9-10):49.

17. Gross G, Drescher K. The role of dopamine $D(3)$ receptors in antipsychotic activity and cognitive functions. Handb Exp Pharmacol. 2012;213(213):167-210.
18. Marder S, Laszlovszky I, Szalai E, Szatmári B, Harsányi J, Barabássy A, et al. Efficacy of cariprazine on predominant negative symptoms of patients with schizophrenia: post hoc analysis of PANSS data, Marder factors, and cognition. Eur Neuropsychopharmacol 2016;26:S550.

19. Nakajima S, Gerretsen P, Takeuchi H, Caravaggio F, Chow T, Le Foll B, et al. The potential role of dopamine $D$ receptor neurotransmission in cognition. Eur Neuropsychopharmacol. 2013;23(8):799813.

20. Carnicella S, Drui G, Boulet S, Carcenac C, Favier M, Duran T, et al. Implication of dopamine $D 3$ receptor activation in the reversion of Parkinson's disease-related motivational deficits. Transl Psychiatry. 2014 Jun 17;4(6).

21. Celada P, Bortolozzi A, Artigas F. Serotonin $5-\mathrm{HT} 1 \mathrm{~A}$ receptors as targets for agents to treat psychiatric disorders: rationale and current status of research. CNS Drugs. 2013 Sep 1;27(9):703-16.

22. Nikiforuk A. Targeting the Serotonin 5-HT7 Receptor in the Search for Treatments for CNS Disorders: Rationale and Progress to Date. CNS Drugs 2015 294. 2015 Feb 27;29(4):265-75.

23. Stahl SM. Stahl's essential psychopharmacology : neuroscientific basis and practical applications (5th ed.). Cambridge, UK ; New York: Cambridge University Press; 2021.

24. Zajecka J, Kornstein SG, Blier P. Residual Symptoms in Major Depressive Disorder: Prevalence, Effects, and Management. J Clin Psychiatry. 2013 Apr 15;74(4):0-0.

25. Ionescu DF, Rosenbaum JF, Alpert JE. Pharmacological approaches to the challenge of treatment-resistant depression. Dialogues Clin Neurosci. 2015 
2;17(2):111.

26. Belujon P, Grace AA. Dopamine System Dysregulation in Major Depressive Disorders. Int J Neuropsychopharmacol. 2017 Dec 1;20(12):1036-46.

27. Montgomery SA. The under-recognized role of dopamine in the treatment of major depressive disorder. Int Clin Psychopharmacol. 2008 Mar;23(2):63-9.

28. Jović J, inić N. Uticaj dopaminergičkog sistema na zavisnost od interneta. Acta medica Medianae. 2011; 50(1):60-66.

29. Duric V, Banasr M, Franklin T, Lepack A, Adham N, Kiss B, et al. Cariprazine Exhibits Anxiolytic and Dopamine D3 Receptor-Dependent Antidepressant Effects in the Chronic Stress Model. Int J Neuropsychopharmacol. 2017 Oct 1;20(10):788-96.

30. Calabrese F, Tarazi FI, Racagni G, Riva MA. The role of dopamine $D 3$ receptors in the mechanism of action of cariprazine. CNS Spectr. 2020 Jun 1;25(3):343-51.

31. Stahl SM. Mechanism of action of cariprazine. CNS Spectr. 2016 Apr 1;21(2):123-7.

32. Frankel JS, Schwartz TL. Brexpiprazole and cariprazine: distinguishing two new atypical antipsychotics from the original dopamine stabilizer aripiprazole. 2016 Oct 17;7(1):29-41.

33. Leggio GM, Bucolo C, Platania CBM, Salomone S, Drago F. Current drug treatments targeting dopamine D3 receptor. Pharmacol Ther. 2016 Sep 1;165:164-77.

34. Citrome L. Cariprazine: chemistry, pharmacodynamics, pharmacokinetics, and metabolism, clinical efficacy, safety, and tolerability. 2013 Feb;9(2):193-206.

35. Cooper H, Mishriky R, Antoun Reyad A. Efficacy and safety of cariprazine in acute management of psychiatric disorders: a meta-analysis of randomized controlled trials. Psychiatr Danub. 2020 Apr 16;32(1):36-45.

36. Suppes T, Ostacher M. Mixed features in major depressive disorder: diagnoses and treatments. CNS Spectr. $2017 \mathrm{Apr}$ 1;22(2):155-60.

37. Diagnostic and Statistical Manual of Mental Disorders (5th ed.; DSM-5; American Psychiatric Association, 2013. https://doi.org/10.1176/appi. books.9780890425596

38. Stegenga BT, Kamphuis MH, King M, Nazareth I, Geerlings MI. The natural course and outcome of major depressive disorder in primary care: the PREDICT-NL study. Soc Psychiatry Psychiatr Epidemiol. 2012;47(1):87-95.

39. Paul R, Andlauer TFM, Czamara D, Hoehn D, Lucae S, Pütz B, et al. Treatment response classes in major depressive disorder identified by model-based clustering and validated by clinical prediction models. Transl Psychiatry 2019 91. 2019 Aug 5;9(1):1-15.

40. Stahl, S., Morrissette, D., Faedda, G., Fava, M., Goldberg, J., Keck, P., . . McIntyre, R. (2017). Guidelines for the recognition and management of mixed depression. CNS Spectrums, 22(2), 203-219.

41. Stahl SM. Mixed-up about how to diagnose and treat mixed features in major depressive episodes. CNS Spectr. 2017 Apr 1;22(2):111-5.

\section{Sara Dodić,}

Klinika za psihijatriju, Univerzitetski klinički centar Srbije, Pasterova 2, 11000 Beograd 